\title{
Municipal financial vulnerability in pandemic crises: a framework for analysis
}

\author{
Emanuele Padovani \\ Department of Management, University of Bologna, Bologna, Italy \\ Silvia Iacuzzi \\ Department of Economics and Statistics, University of Udine, Udine, Italy \\ Susana Jorge \\ Faculty of Economics, University of Coimbra, Coimbra, Portugal and \\ CICP - Research Centre in Political Science, University of Minho, \\ Braga, Portugal, and \\ Liliana Pimentel \\ CeBER, Faculty of Economics, University of Coimbra, Coimbra, Portugal
}

\section{Assessing financial vulnerability in crises}

387

Received 19 July 2020

Revised 23 October 2020

11 December 2020

13 December 2020

Accepted 16 December 2020

\begin{abstract}
Purpose - This paper explores how global pandemic crises affect the financial vulnerability of municipalities. Design/methodology/approach - This paper is developed from the relevant literature an analytical framework to examine municipal financial vulnerability before a global pandemic crisis and in its immediate aftermath by mapping and systematizing its dimensions and sources. To illustrate how it can be used and evaluate its robustness and flexibility, such a tool was applied to Portugal and Italy, two countries that particularly suffered from the Covid-19 crisis.

Findings - The application of the analytical framework has shown how financially vulnerable municipalities are to global pandemic crises. Financial vulnerability relates to issues ranging from institutional design to internal financial conditions and the perception of the capacity to cope with a crisis. Results further reveal that vulnerability has an inherent contingent nature in time and space and can lead to paradoxical outcomes.

Research limitations/implications - This paper provides a tool that can be useful for both academic and public policy purposes, to further appreciate municipal financial vulnerability, especially during crises.
\end{abstract}

(C) Emanuele Padovani, Silvia Iacuzzi, Susana Jorge and Liliana Pimentel. Published by Emerald Publishing Limited. This article is published under the Creative Commons Attribution (CC BY 4.0) licence. Anyone may reproduce, distribute, translate and create derivative works of this article (for both commercial and non-commercial purposes), subject to full attribution to the original publication and authors. The full terms of this licence may be seen at http://creativecommons.org/licences/by/4.0/ legalcode

The authors gratefully acknowledge the comments received from the Local Government Financial Sustainability Across countries (LGFSAcross) network, by the editor and the two anonymous reviewers during the review process. The paper is the outcome of the authors' joint work. However, in the final version Susana Jorge was responsible for the "Introduction" and the "Final remarks", Silvia Iacuzzi was responsible for the "Literature overview", Emanuele Padovani was responsible for "A proposal for an analytical framework for financial vulnerability", Liliana Pimentel was responsible for the "Discussion", and all authors were jointly responsible for the section "Analyzing municipal financial vulnerability: the cases of Portugal and Italy".

The authors also would like to acknowledge that this study was partially conducted at the Research Center in Political Science (UIDB/CPO/00758/2020), University of Minho and supported by the Portuguese Foundation for Science and Technology (FCT) and the Portuguese Ministry of Education and Science through national funds. It was also conducted at the Centre for Business and Economics Research, I\&D unit funded by national funds through FCT - Fundação para a Ciência e a Tecnologia, I.P., Project UIDB/05037/2020.

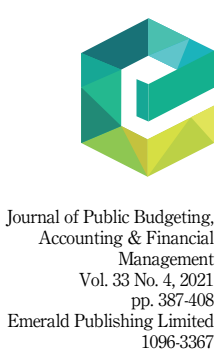

DOI 101108/PBAFM 1096-336 
JPBAFM 33,4
Practical implications - Municipalities can use the framework to better manage their financial vulnerability, strengthening their anticipatory and copying capacities, while oversight authorities can use it to help municipalities become less financially vulnerable or, at least, more aware of their financial vulnerability. Originality/value - Municipal financial vulnerability to global shocks has not been explored extensively. Also, the Covid-19 pandemic is different from previous global crises as it affected society overnight with the implementation of lockdown and social distancing measures.

Keywords Financial management, Local governments, Financial vulnerability, Crises

Paper type Research paper

\section{Introduction}

Municipalities have a direct impact on people's life as they influence the functioning of local economies, the delivery of national governments' policies and that of proximity services, such as public health, security and education. Thus, it is not surprising that municipalities have played a central role both in recent reforms and crises.

On the policy side, the last 30 years have been characterized first by a decentralization and an increase in local autonomy, and, in a second instance, by recentralization efforts cutting back local powers and resources while intensifying upper-level control and supervision measures (Pollitt and Bouckaert, 2017).

As far as crises are concerned, they have attracted the attention of scholars particularly following the 2008 financial crisis, which has made it imperative to appreciate how municipalities react to such events. It is interesting to explore reactions to the same crisis, because the characteristics of municipalities vary across countries: they depend upon the federal or unitary nature of their country, the number and sizes of municipalities and different administrative traditions and arrangements (Saliterer et al., 2017).

However, even after the 2008 crisis, the literature on the public administration response to global crisis has mainly focused on public policy issues (Peters, 2011) or crisis management (Boin and Lodge, 2016), less so on how financially vulnerable municipalities are to external shocks. On the other hand, the literature on financial vulnerability has focused mainly on financial condition and performance (Cabaleiro et al., 2013), less so on resilience, that is how municipalities face and absorb external shocks, with a few notable exceptions (Barbera et al., 2017, 2020; Steccolini et al., 2017).

In their recent definition, Barbera et al. (2020, p. 533) claim that vulnerability is the "reduced capacity to cope with emerging shocks". Likewise, Arunachalam et al. (2017, p. 52) define a local council as vulnerable when without some structural reform and major revenue and expense adjustments, "is highly unlikely to be able to manage unforeseen financial shocks and any adverse changes in its business and in general economic conditions". This paper considers these different understandings and perspectives of municipal financial vulnerability and develops a framework to analyze its multifaceted sources. Hence, the main research questions are:

How can municipal financial vulnerability to global pandemic crises be analyzed?

Which sources of financial vulnerability should be considered in this process?

Starting from a review of the relevant theoretical concepts, this paper proposes a framework to appreciate how financially vulnerable municipalities are before and in the immediate aftermath of a global pandemic crisis. This framework considers internal, external and perceived sources of financial vulnerability, deriving different perspectives for analysis. The framework is then applied to two European countries that have been heavily impacted by the Covid-19, namely Portugal and Italy, which are used as illustrative cases for the application of the model. Portugal and Italy have a Napoleonic tradition (Ongaro, 2008), but different municipal characteristics, so much that they epitomize diverse case studies (Seawright and Gerring, 2008). Hence, the study offers a viewpoint on municipal financial 
vulnerability in times of pandemic crisis affecting financial vulnerability in two countries, while showing how the proposed framework can be applied to different geographical contexts. The discussion summarizes the main findings, while a final section offers additional insights about the implications and limitations of the proposed framework.

\section{Literature overview}

Recent publications on the impact of Covid-19 have highlighted the need for a rigorous and scientific debate on this pandemic crisis and its consequences at different levels, so as to inform effective public governance (Grossi et al., 2020; Trombetta, 2020). This paper contributes to the debate by focusing on municipal financial vulnerability and the nature of the global shocks that affect it, both meriting a more in-depth analysis.

\section{Municipal financial vulnerability}

The financial vulnerability of public administration has been studied by scholars at a macroeconomic level for a long time, especially with reference to natural disasters and with a country perspective (e.g. Pollner et al., 2001). There is overall agreement that financial vulnerability is a dimension of financial resilience, which is the capacity to deal with shocks affecting government finances so as to retain essentially the same function, structure and identity (Walker et al., 2002). At the municipal government level, the literature on financial vulnerability seems quite scant and mostly related to the global financial crisis of 2008 with different conceptualizations and operationalizations.

The concept of municipal financial vulnerability was first used by the Canadian Institute of Chartered Accountants in 2009 (Zafra-Gómez et al., 2009; Cabaleiro et al., 2013) as one of the components together with flexibility and sustainability of municipal financial condition, defined as the ability to meet existing financial obligations, including both public service commitments to residents and businesses and financial commitments to creditors and employees. In this context, financial vulnerability is understood as "the extent to which the organization depends on resources that are beyond its own control or influence" (Cabaleiro et al., 2013, p. 733); it can be used as one of the indicators of budgetary solvency (Bisogno et al., 2019). Indeed, municipalities may both benefit from transfer payments from higher tiers of governments and levy their own taxes and service charges (UCLG, 2019). Despite any guarantee of financial support from the central government in the event of financial rupture, evidence suggests that municipalities face more financial risks when they rely on intergovernmental revenues: they are more likely to mismanage public finances due to "moral hazard" (Lobo and Ramos, 2011; Persson and Tabellini, 1996) and their revenue inflows are more vulnerable, since decisions about them are made by other entities (Martell, 2008; Bastida et al., 2014). Revenue sources represent just a part of the broader institutional design of power devolution across tiers of government. Comparative local government studies suggest that not only administrative traditions (Pollitt and Bouckaert, 2017), but also functional, territorial and political profiles vary considerably across countries (Kuhlmann and Wollmann, 2014). Looking at functional issues, higher levels of government monitor local budgets and keep local finances under control by establishing specific fiscal governance regimes that may create budget constraints and foster fiscal adaptation and consolidation pressures. Fiscal rules such as limits to current and capital expenditure financing, debt ceilings, balanced budget requirements (e.g. "golden rule"), may impact financial vulnerability (Barbera et al., 2017). Comparative analyses have shown not only a significant differentiation and complexity across countries, but also a somewhat high level of dynamism within each country after the 2008 global financial crisis (Geissler et al., 2019). Since institutional factors influence how systems of government respond to crisis (Lodge and Hood, 2012), the structure and type of municipal revenues, the degree of decentralization (that is the scope of municipal responsibilities and the functions delivered), the supervision and 
JPBAFM 33,4

390 regulation by higher levels of government are all relevant in determining how financially vulnerable municipalities are in facing the impacts of the Covid-19 pandemic (OECD, 2020b).

Barbera et al. (2017, p. 675) widen Cabaleiro's concept by stating that financial vulnerability is the "result of both external (e.g. dependence on grants) as well as internal (e.g. debt financing, reserves) sources, turning out to be at the interface between the environment and the organization". This perspective emphasizes objective sources of financial vulnerability, which include typical financial elements such as the level of diversification of revenues (Mikesell, 2013), the capacity to sell capital assets (Berne and Schramm, 1986), the availability of cash and financial reserves (Downing, 1991; Jacob and Hendrick, 2012), the level of expenditure rigidity, the connected idea of cost stickiness (Cohen et al., 2017) and non-discretionary expenditures (Maher et al., 2020), the capacity to incur short-term liabilities (Berne and Schramm, 1986), and the debt burden (Capeci, 1994) or any moratorium on debt repayment (Barbera et al., 2017) and changes in the cash flow on debt covenants (Ahrens and Ferry, 2020). The literature also suggests elements that could limit financial vulnerability when facing a crisis: Ahrens and Ferry (2020) mention an insurance for low-probability high-impact events; Barbera et al. (2017) provide evidence about an anticipated approval for supplementary budgets, while Hochrainer (2006) talks generally about provisions for contingent credit.

Furthermore, when analyzing resilience with respect to the financial crisis and consequent austerity measures stemmed from the credit crunch in 2008, Barbera et al. (2017, p. 675) maintain that "rather than an objective measure of vulnerability, it is the perceived vulnerability which proved to be central in understanding patterns of financial resilience". Indeed, municipalities, on the one hand, often lack situation and perspective awareness, sense-making and systems to control and manage risks, and on the other, they do not often enjoy transforming capacities to implement radical changes or even adapting capacities to implement incremental changes. By relying too much on buffering capacities organizations tend to "bounce back" or maintain a status quo, rather than develop the capacities needed to change and progress (Barbera $e$ t al., 2017, 2019): instead of leading the change to the next normal, municipalities often find themselves chasing after it. To be able to perform their critical functions without disruptions, municipalities need to be able to see and plan ahead, to adjust their revenues and expenditures not only to reflect changes over time, but also to deal with adverse fiscal shocks (Wällstedt et al., 2014). Hence, Steccolini et al. (2017, p. 232) conclude that financial vulnerability represents the "perceived exposure to shocks, that is the level and sources of vulnerability and their development over time". Anessi-Pessina et al. (2020, p. 960) maintain that financial vulnerability "is the level of perceived exposure to a specific shock and lies at the interface between shocks and organizational capacities". In other words, it is the sense of being able to control financial vulnerability or influence its sources that affects the way in which shocks are interpreted and subsequently tackled, so much that perceived vulnerabilities play a central role in the anticipatory capacity to face shocks which is, in turn, essential for the implementation of bouncing forward capacities (Barbera et al., 2019). Yet, available information has proved to be highly insufficient to help appreciate the level of financial vulnerability, let alone putting in place effective coping capacities during a crisis (Ahrens and Ferry, 2020).

All in all, considering the discussions in the above literature, three relevant dimensions of financial vulnerability can thus be singled out:

(1) Financial vulnerability related to the external institutional design of municipal administrative structure and fiscal rules; this dimension considers each municipality as an entity embedded in its environment, considering the contingencies created by administrative tradition, rules and decisions set by higher levels of government;

(2) Financial vulnerability related to internal issues of financial condition, described by such generally accepted financial indices as financial dependency ratios, debt burden 
and revenue-expenses balance; this dimension considers each municipality as a single business entity;

(3) Financial vulnerability related to the perception of the capacity to cope with a crisis; this is a more context-related dimension that also considers the availability of information and their interpretation.

Crises: types, space and timing

Crises with their dynamic and chaotic nature, tend to be a challenge to governments (Peters, 2011). Transboundary crises, that cut across geographical, sectorial and policy boundaries such as the Covid-19 pandemic, multiply the strengths of their impacts and make responses much more complex and wicked (Boin and Lodge, 2016). Such global events have attracted the attention of scholars particularly in the past 10 years following the 2008 financial crisis. However, in contrast to the situation during that financial crisis (Davies, 2011), global GDP growth is expected not only to stagnate, but to fall by more than two percent in 2020 because the Covid-19 crisis has affected the real economy, not just financial markets (OECD, 2020a). However, impacts and reactions to the global pandemic have been different across countries and jurisdictions within a country (Maher et al., 2020; Nemec and Špaček, 2020; OECD, 2020b).

Moreover, the current pandemic, beyond having a global reach with local patterns, has spread relatively fast, differently from the 2008 crisis, which first affected financial markets, then the real economy and finally local public finances (Grossi and Cepiku, 2014). In other words, the 2008 crisis had a slow-onset, while the 2020 crisis has had a sudden-onset (Hochrainer, 2006), since it has generally affected local services overnight, in correspondence with the implementation of lockdown and social distancing measures.

Further, according to several authors it is not to be underestimated that the 2008 financial crisis and the subsequent austerity measures, depending if, where and how they were implemented, may have weakened local governments' ability to face the 2020 crisis (Ahrens and Ferry, 2020; OECD, 2020b).

This underlines once more the temporal dimension that Pollitt (2008) considers crucial in many public policy and management problems. From his "time toolkit", the duration, path, window of opportunity and perspective elements seem relevant to this analysis. The Covid-19 pandemic struck in the winter 2020 and is still undergoing. One can thus understand and analyze only the onset and the immediate aftermath of a pandemic that is still unclear when and how it will end. One can now grasp only the consequences of the measures taken in the spring and the summer of 2020 in different countries. There might also be a time-lag effect, so that despite the approval of new regulations that shape the external institutional design, their consequences might become evident only at a later stage.

Hence, time and space play a crucial role in analyzing the consequences of the Covid-19 pandemic. This paper looks at municipal financial vulnerability developing an analytical framework which takes into consideration both spatial contingencies, in terms of geography and sector, and time dynamics, as far as the speed of the pandemic and the perspective of the analysis (before and immediate aftermath) are concerned.

\section{A proposal for an analytical framework for financial vulnerability}

As seen above, in the literature financial vulnerability is seen as the contingent and dynamic combination of internal and external dimensions to municipalities as well as perception related to the capacity to cope with crisis. Thus, an analytical framework is developed to understand how financially vulnerable municipalities are, analyzing whether and how the aspects of the different dimensions of financial vulnerability change immediately after a crisis in different jurisdictions. 
JPBAFM 33,4

392
First of all, each dimension of financial vulnerability can affect different fields investigated to appreciate it. As seen in the literature overview, the external dimension is characterized by outside forces and institutional factors (Lodge and Hood, 2012, Kuhlmann and Wollmann, 2014; Pollitt and Bouckaert, 2017). These in turn concern different administrative structures, for example the level of centralization vis à vis the level of autonomy of municipalities, as well as different fiscal rules, i.e. centrally defined policies including the structure, basis and controllability of major revenue sources, debt rules, investment guidelines, monitoring systems, tax limits, etc., which shape municipalities' room for maneuver during a crisis (Steccolini et al., 2017).

Moreover, a municipality revenue and expenditure structure are influenced both by external institutional factors as well as by internal financial condition. For example, in the aftermath of the 2008 financial crisis, austerity measures at higher levels filtered down to the local level and impacted the resources available to deliver services to local communities (Brusca et al., 2015). On the contrary, with the Covid-19 pandemic many higher government tiers supported local authorities less able to collect local taxes and tariffs (OECD, 2020b). Indeed, in the face of lockdowns and economic standstills, revenues become ever more uncertain because tax bases shrink, while unemployment and social inequality increase, thereby increasing the demand for social services (Pollitt and Bouckaert, 2017). At the same time, their rigidity may make increasing expenditures to support local communities impossible. Moreover, high levels of debt may lead to non-controllable liabilities and financial risks or there may be rules regarding debt ceilings preventing to resort to debt for extra resources. Moreover, the OECD and the World Bank observe that central government support to municipalities during crises is often ad hoc and unplanned and can create large implicit contingent liabilities (OECD and World Bank, 2019). Observers have highlighted that policy tools used to counteract the impacts of the Covid-19 crisis have had a lot of similarities across countries, even though the sheer financial magnitude of such responses has varied extensively across jurisdictions (de Jong and Ho, 2020). Some municipalities have received funding to support specific Covid19 expenditures, others have been allowed to run deficits, while many central governments have intervened directly to support businesses and families (Anessi-Pessina et al., 2020).

Lastly, the perception of the capacity to cope with a crisis is characterized not only by administrative structures, fiscal rules and revenue and expenditure structure, but also by the outlook regarding municipalities ability to manage their internal capacities and to use and shape the external environment to weather a crisis (Steccolini et al., 2017).

Therefore, four fields of enquiry can be singled out in investigating the three dimensions of financial vulnerability before and in the aftermath of a pandemic crisis: (1) the overall administrative structure and fiscal rules, (2) the municipal revenue structure, (3) the municipal expenditure structure and (4) the vulnerability outlook, as in Figure 1.

From the literature overview it further emerges that in the contingent and dynamic appreciation of a global, fast-spreading crisis (Ahrens and Ferry, 2020), the sources of financial vulnerability in each field of enquiry can be grouped into two types: lack of anticipatory capacity and lack of coping capacity (Barbera et al., 2017, 2019, 2020). Anticipatory capacities refer to tools and capabilities that are built up before a crisis arises to enable municipalities "to better identify and manage their vulnerabilities and recognize potential financial shocks" (Barbera et al., 2017, p. 675). Coping capacities instead are resources and abilities that "lie dormant in times of order" and "allow shocks to be faced and vulnerabilities to be managed” at times of disruption (Barbera et al., 2017, p. 675).

Table 1 completes the analytical framework and illustrates a summary of the sources of financial vulnerability suggested by the literature for each field of enquiry.

The sources of financial vulnerability can be appreciated and appraised through qualitative or quantitative indicators, depending on the data generally collected and 


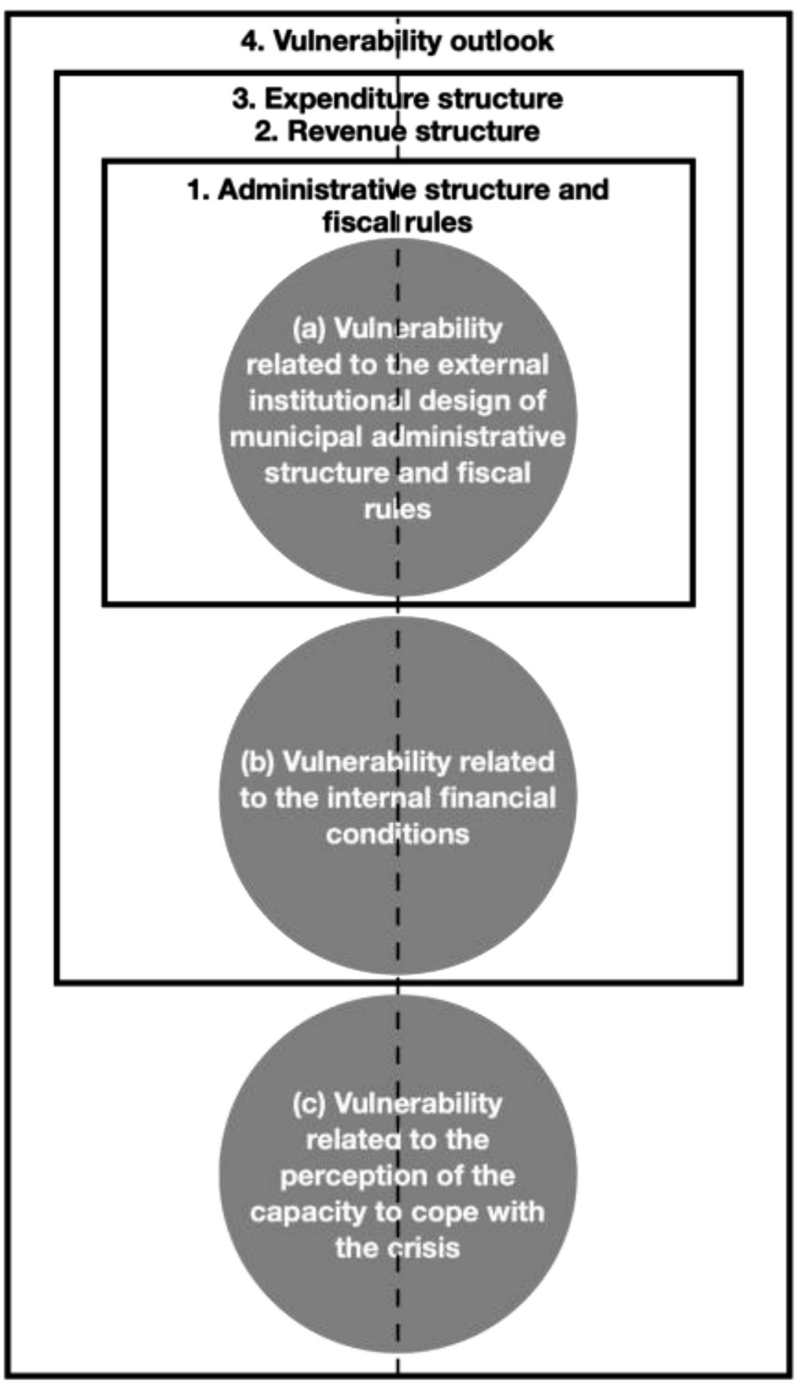

\section{BEFORE CRISIS AFTER}

\section{Assessing financial vulnerability in crises \\ 393}

Key:

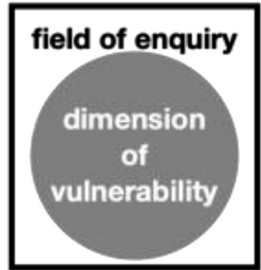

Figure 1.

Analytical framework: fields of enquiry and dimensions of municipalities' financial vulnerability

available in a country, its accounting system, its administrative traditions, and so on. For example, the extent to which a municipality depends on own resources that it can control and influence can be measured through indices such as the ratio between own-source current revenues (that is, local taxes and fees) and total current revenues, the ratio between own-source current revenues and current transfers, the ratio between own-source current revenues and current costs or the ratio between own-source current revenues and inhabitants (Cabaleiro et al., 2013). There is a wide and mature literature that provides a plethora of possible key financial performance indicators as measures for different dimensions of financial vulnerability and in particular for revenue and expenditure 
JPBAFM 33,4

\section{4}

\begin{tabular}{lll}
$\begin{array}{l}\text { Vulnerability } \\
\text { dimension }\end{array} \quad$ Field of enquiry & $\begin{array}{l}\text { Type of } \\
\text { vulnerability } \\
\text { sources }\end{array} \quad$ Sources of vulnerability \\
\hline
\end{tabular}

$\begin{array}{lll}\text { (a) External } & \text { Administrative } & \text { Lack of } \\ \text { institutional design } & \begin{array}{l}\text { structure and fiscal } \\ \text { rules }\end{array} & \begin{array}{l}\text { anticipatory } \\ \text { capacities }\end{array}\end{array}$

Lack of coping capacities

(a) External institutional design

\section{Revenue structure}

Lack of anticipatory capacities
Lack of coping capacities
(1) Absence/limited rules on debt and deficit (Lodge and Hood, 2012)

(2) Lack of formalized spending reviews as a framework for annual budgets to increase efficiency (Ahrens and Ferry, 2020)

(3) Public sector audits which fail to scrutinize readiness for urgent crises concerning low probability high impact events (Ahrens and Ferry, 2020)

(4) No/limited possibility to relax fiscal rules such as limits to current and capital expenditure financing, debt ceilings, balanced budget requirement, etc. (Barbera et al., 2017)

(1) Dependency on transfers and limited own resources (Ahrens and Ferry, 2020; Mikesell, 2013)

(2) Lack/limited cash and/or financial reserves (Ahrens and Ferry, 2020; Barbera et al., 2017; Downing, 1991; Hochrainer, 2006; Jacob and Hendrick, 2012)

(3) Lack of anticipated approval of supplementary budget (Barbera et al., 2017)

(4) Lack of insurance for low probability - high impact events (Ahrens and Ferry, 2020; Hochrainer, 2006)

(5) Lack of provisions for contingent credit (Hochrainer, 2006)

(6) No/limited possibility to sell assets (Barbera et al., 2017; Berne and Schramm, 1986)

(7) No/limited possibility of increasing fees and charges (Barbera et al., 2017)

(8) No/limited possibility increasing debts (loans) (Barbera et al., 2017; Berne and Schramm, 1986; Hochrainer, 2006)

Table 1. 


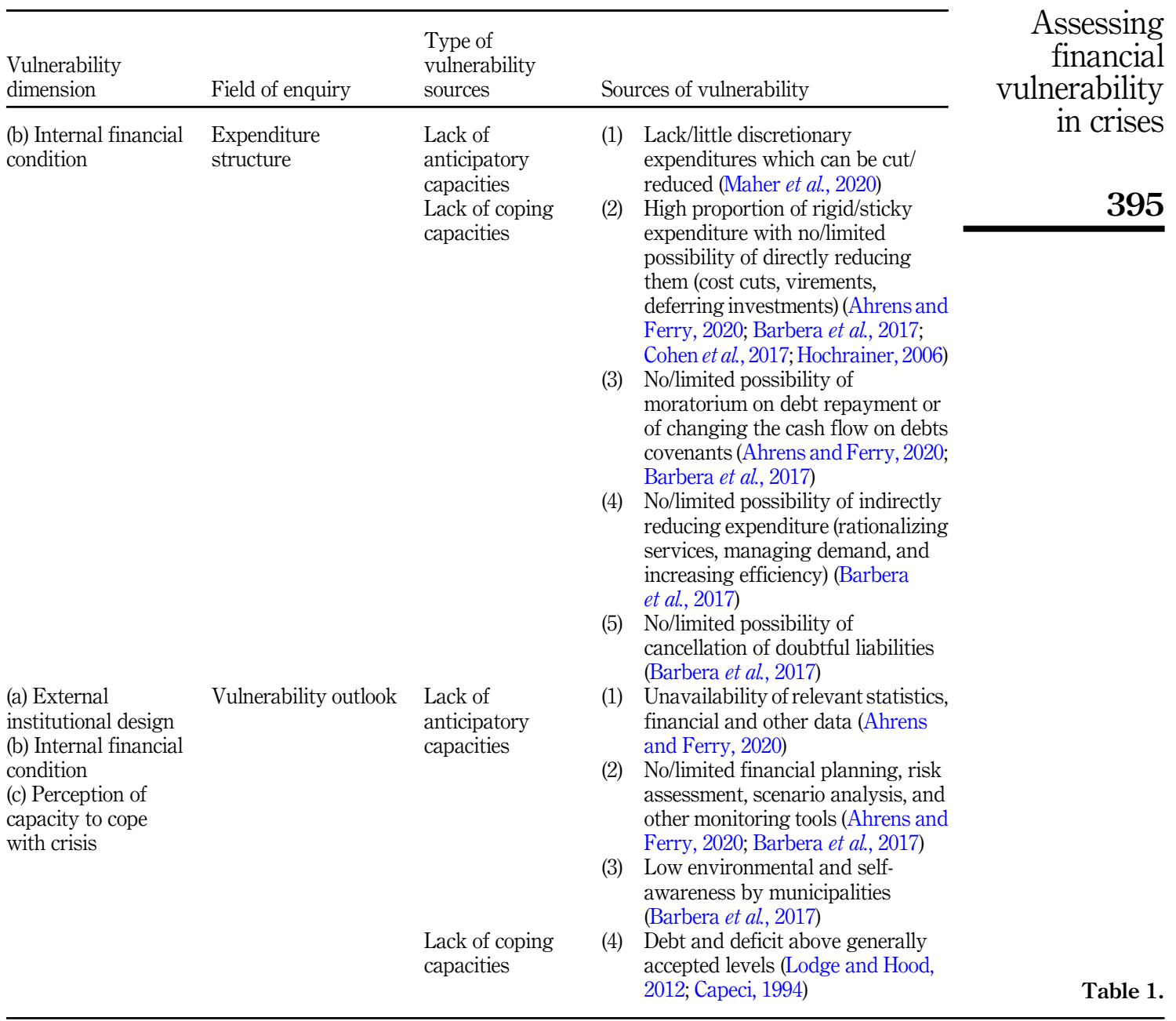

structure (e.g. Groves et al., 1981; Zafra-Gómez et al., 2009; Maher and Deller, 2011; Wällstedt et al., 2014; Bisogno et al., 2019). Hence, the set of indicators for each source of financial vulnerability may not be the same because they are calculated in different ways or using data collected differently across countries and entities. They may not even be available for all countries or all entities within a country or they may be available with a significant time delay or only before a crisis and not during its onset or aftermath. Taking this into account, both qualitative (e.g. anticipated budget approvals, debt rules, audits) and quantitative (e.g. the degree of autonomy over income sources, expenditure rigidity, debt levels and reliance on non-controllable initiatives) indicators of financial vulnerability represent interesting juxtapositions from which to compare municipal financial vulnerability and responses to the Covid-19 crisis.

On the other hand, the contingent nature of financial vulnerability is confirmed by the fact that some of its sources have been identified in the literature as having the opposite effect on 
JPBAFM

33,4

396 resilience in the long run. For example, Barbera et al. (2019) point out that increasing taxes and fees, deferring investments, reducing the costs, the scope or the size of services or of the organization, as well as selling assets may all be components of bouncing back strategies, such as retrenchment, buffering, downsizing, cutbacks. Yet, in the long run such strategies may not favor resilience, while bouncing forward strategies such as transformation, repositioning, and reorientation would support it. Hence, in a time dynamic perspective, bouncing back strategies may help reduce financial vulnerability in the aftermath of a crisis, but not necessarily help resilience in the long run.

The following section illustrates the application of the above framework to Portugal and Italy. This exercise allows, on the one hand, to better understand financial vulnerability in practice, highlighting how to apply such concept and whether, where, and how it changed with the pandemic. On the other hand, it allows verifying that the proposed analytical model is both solid and flexible enough to accommodate the experience of different jurisdictions using different indicators, when similar ones are not available.

\section{Analyzing municipal financial vulnerability: the cases of Portugal and Italy}

There are important differences between Italian and Portuguese municipalities, starting from the fact that whereas Italy is quite decentralized, Portugal is still rather centralized. However, both countries enjoy Napoleonic administrative traditions (Ongaro, 2008). Hence, somewhat different contexts have impacted vulnerability differently, but a closer look reveals that the measures taken by the two countries to counter the Covid-19 crisis not only are similar, but have similar impacts on financial vulnerability. The illustration of the proposed analytical framework for the two countries is based on legislation and reports by the respective ministries, municipalities' associations and central auditing bodies, as referred to in Table 2.

\section{Portugal}

Since the late 1970s, according to the Constitution, Portuguese municipalities are autonomous, defining their own budget and managing local resources, such as service fees, property, and local taxes. Currently, there are 186 small municipalities with up to 20,000 inhabitants, 98 medium size municipalities with between 20,000 and 100,000 inhabitants and 24 large municipalities with over 100,000 inhabitants. The 308 municipalities have attributions established by law for: rural and urban equipment; energy; transport and communications; education (excluding universities and teaching staff); heritage, culture and science; leisure and sports; health (excluding hospitals, doctors and nurses); social care; housing; civil protection; environment and basic sanitation; consumer protection; promotion of development; local planning; municipal police and external cooperation. However, they are subject to administrative tutelage and benefit from a share of public resources coming from the central government via transfers and grants. Despite their autonomy, Portuguese municipalities are responsible for only about $13 \%$ of the total public expenditure and $14 \%$ of the total public revenue, quite below the average among OECD countries of about $24 \%$ for both (Fernandes et al., 2019).

Overall, there is no clear measure of financial vulnerability, which before the austerity measured implemented in 2011 was characterized by: unsustainable debt levels, inflated budgets allowing for uncontrolled expenditure, high amounts of arrears and very long payment periods (Fernandes et al., 2019). The effects of several laws imposing fiscal discipline also to municipalities started to be felt from 2014. By the end of 2019 about $80 \%$ of municipalities had overcome some previous vulnerability issues, creating financial cushions and making them more resilient to crises.

The Covid-19 pandemic led to yet another package of legislative measures, which allowed to suspend or extend limits and deadlines for the forthcoming one to two years, and to relax 

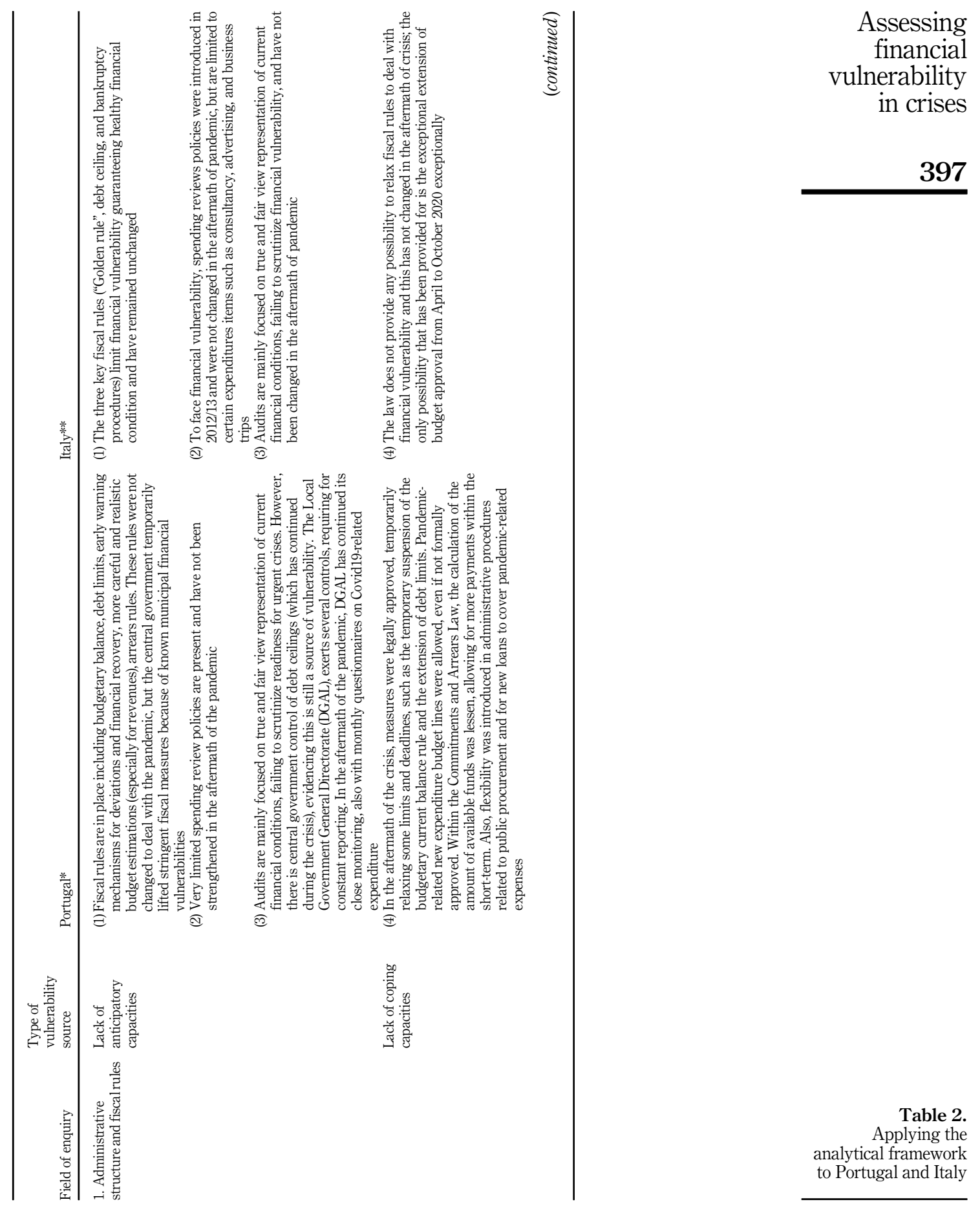

Table 2.

Applying the analytical framework to Portugal and Italy 


\section{JPBAFM 33,4}

398
意

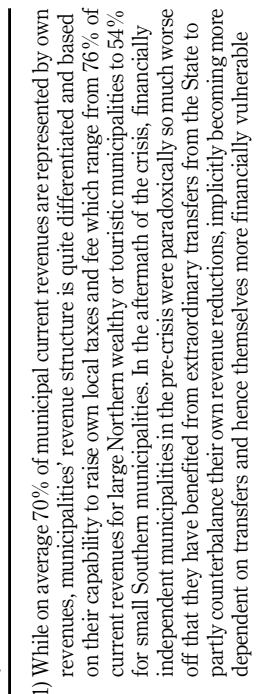

$\Xi$

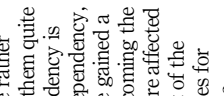

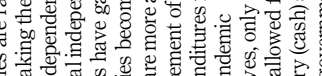

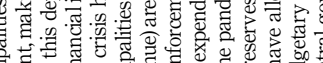

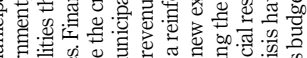

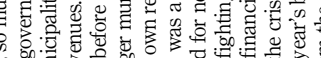

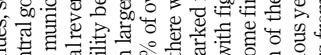

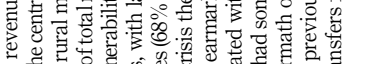

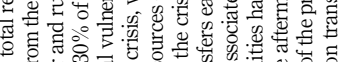

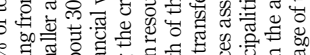

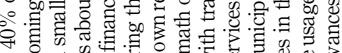

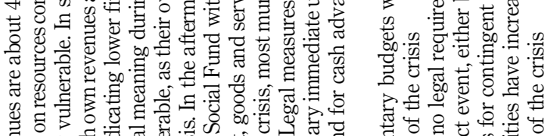

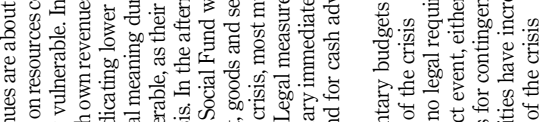

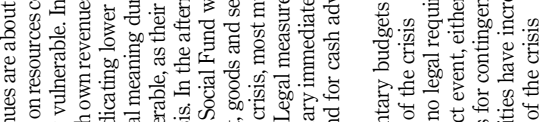

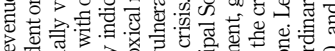

要

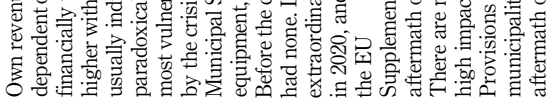

สิ

$$
\text { 通过 }
$$

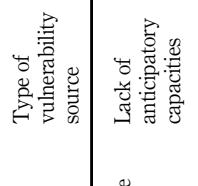

Table 2.

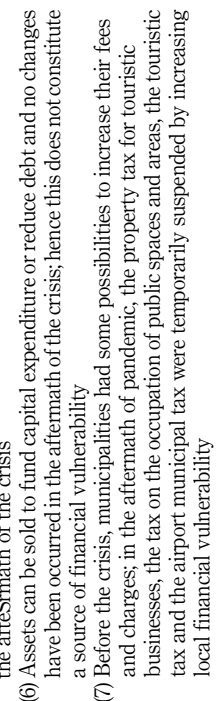

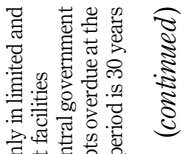

कै द्ष

记

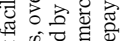

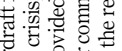

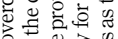

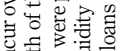

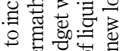

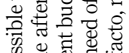

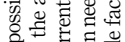

on

in

:

Eु

苟

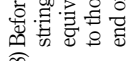

क्

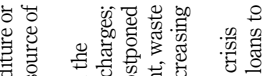

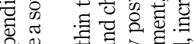

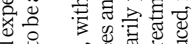

है

苋菅 (a)

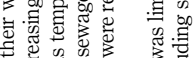

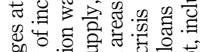

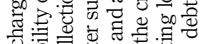

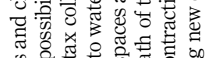

\%

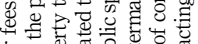

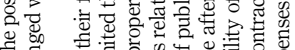

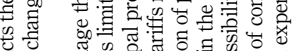

药

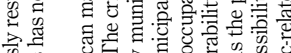

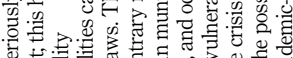

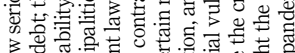

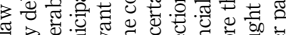

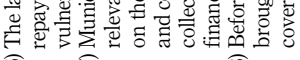

(a)

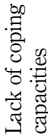




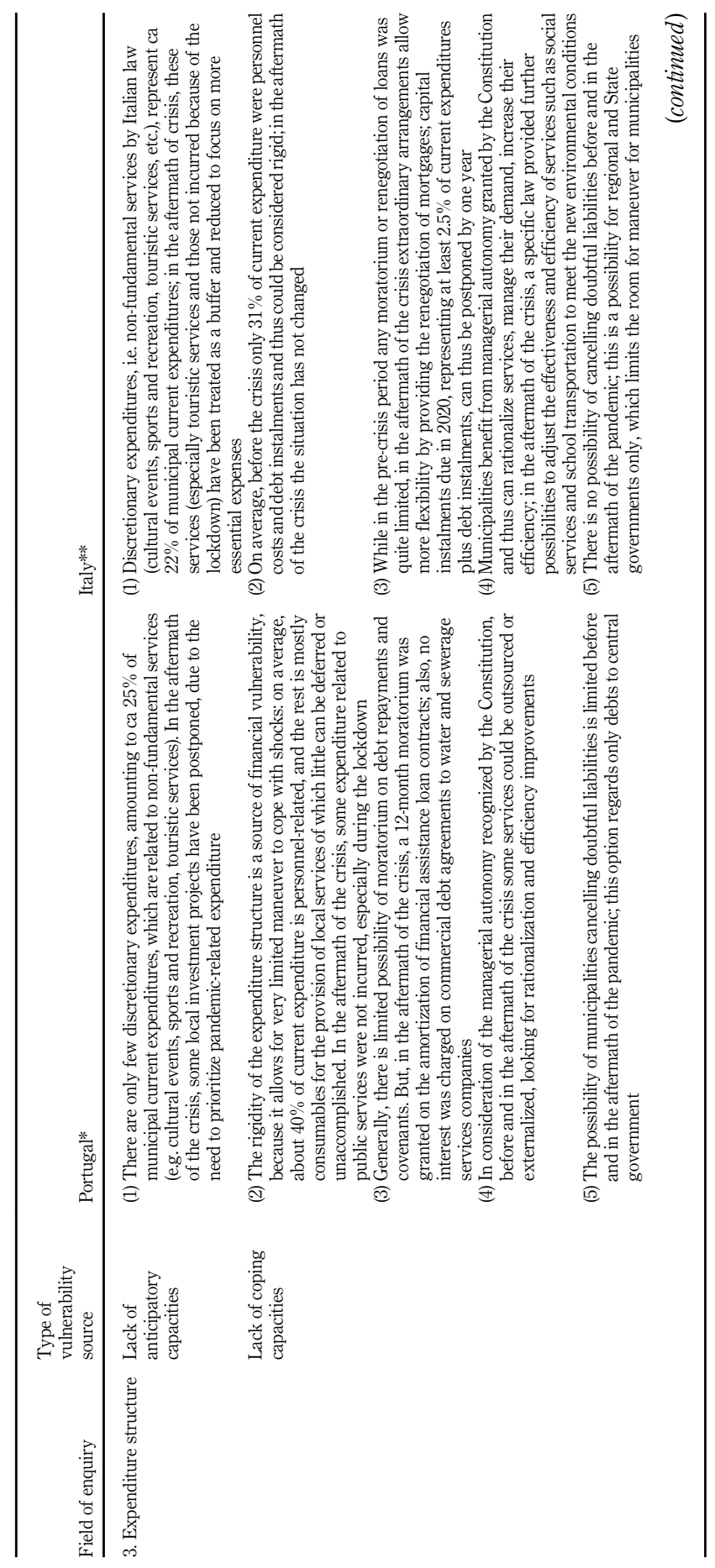




\section{JPBAFM 33,4}

400
糔

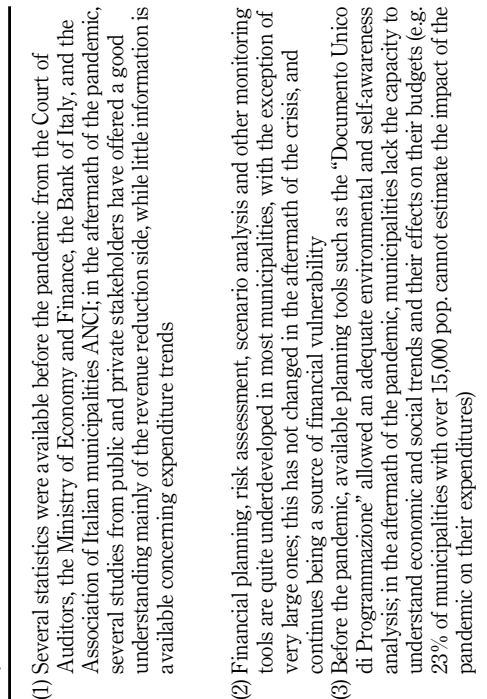

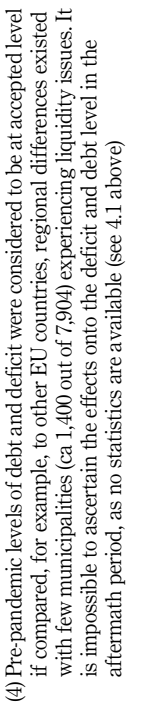

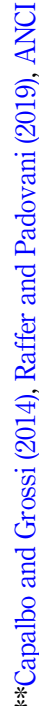

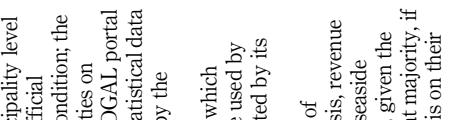

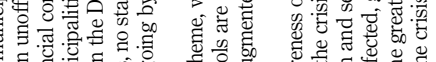

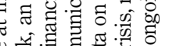

济

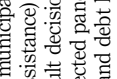

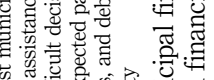

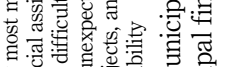

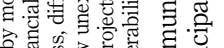

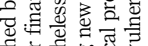

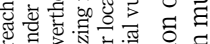

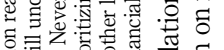

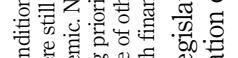

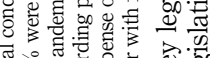

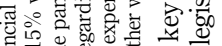

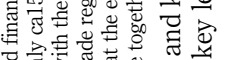

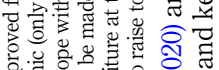

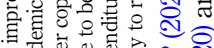

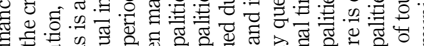

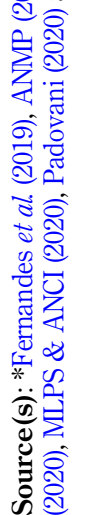

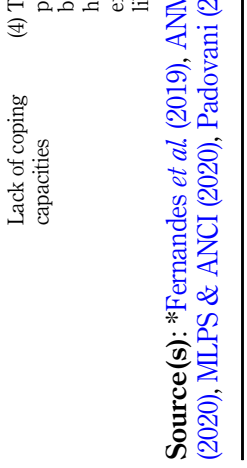

Table 2.

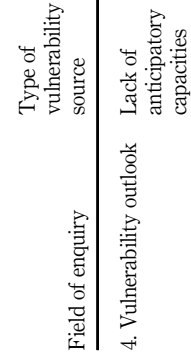


several administrative controlling procedures. These temporary measures are not affecting substantially the financial regime further revised in 2018.

\section{Italy}

Italy is a unitary country with a highly regionalized structure (Bettoni, 2017). Beneath the central government, the local level consists of municipalities, municipality unions, metropolitan cities, provinces, and regions. Decentralization began in the 1990s, with the direct election of mayors, and culminated in 2009 with fiscal federalism. Local selfgovernment is a constitutionally enshrined right (Bespalova and Knud, 2013). The 7,904 municipalities represent the local authorities closest to the citizens. A total of $56 \%$ of them have up to 3,000 inhabitants and the average population is slightly more than 7,500 inhabitants, depicting a highly fragmented setting with respect, for example, to Portugal. In general, municipal responsibilities include fundamental services such as town planning, building and commercial permits, social housing, local police, public transport and roads, water and waste management, education (pre and primary school buildings), social services, local economic development, but also non-fundamental services such as cultural events, sports, recreation and touristic services, which depend on local needs, conditions, traditions and so on.

Municipal financial vulnerability was usually measured through proxies such as doubtful accounts receivable, off-balance debt (i.e. not-budgeted-for current expenditures) and arrears, that is overdue debts (Raffer and Padovani, 2019).

To face the Covid-19 pandemic in March and May 2020 the central government issued the "Cure Italy decree" and the "Relaunch decree" respectively, which offered some respite but devolved no extraordinary powers to municipalities.

\section{Applying the analytical framework}

The proposed model allows to review the issues that influenced municipal financial vulnerability before the pandemic and as the Covid-19 crisis unfolded in both countries. Table 2 summarizes the issues that emerged applying the analytical framework to Portugal and Italy. The data collected for the various sources of vulnerability follows from the studies outlined above, from information in national legislation and reports, and could be connected to that stemming from other related qualitative and quantitative indicators.

\section{Discussion}

The application of the analytical framework, looking at the financial condition of municipalities in the pre-Covid period and in the aftermath of the pandemic, has revealed how financially vulnerable Portuguese and Italian municipalities were to global crises. The analysis allows to appreciate which are the most important fields and sources of financial vulnerability, whether they relate to anticipatory or coping capacities, and what were the changes induced by the crisis. This exercise shows how spatial and time contingencies affect financial vulnerability in municipalities, since it evidences differences over time, that is before and in the aftermath of the crisis, and space, that is between and within countries.

It is then possible to arrive at a representation like that provided in Table 3 , which further summarizes the impact of the Covid-19 crisis on municipal financial vulnerability in the two countries allowing for immediate spatial and time comparisons.

The analysis in Tables 2 and 3 shows that, in both Portugal and in Italy, the administrative structure and financial regime were not changed to deal with the pandemic: no extraordinary powers were granted to municipalities which could thus react only within their ordinary administrative and fiscal frameworks. In Portugal some fiscal rules and an ongoing

\section{Assessing financial vulnerability in crises}




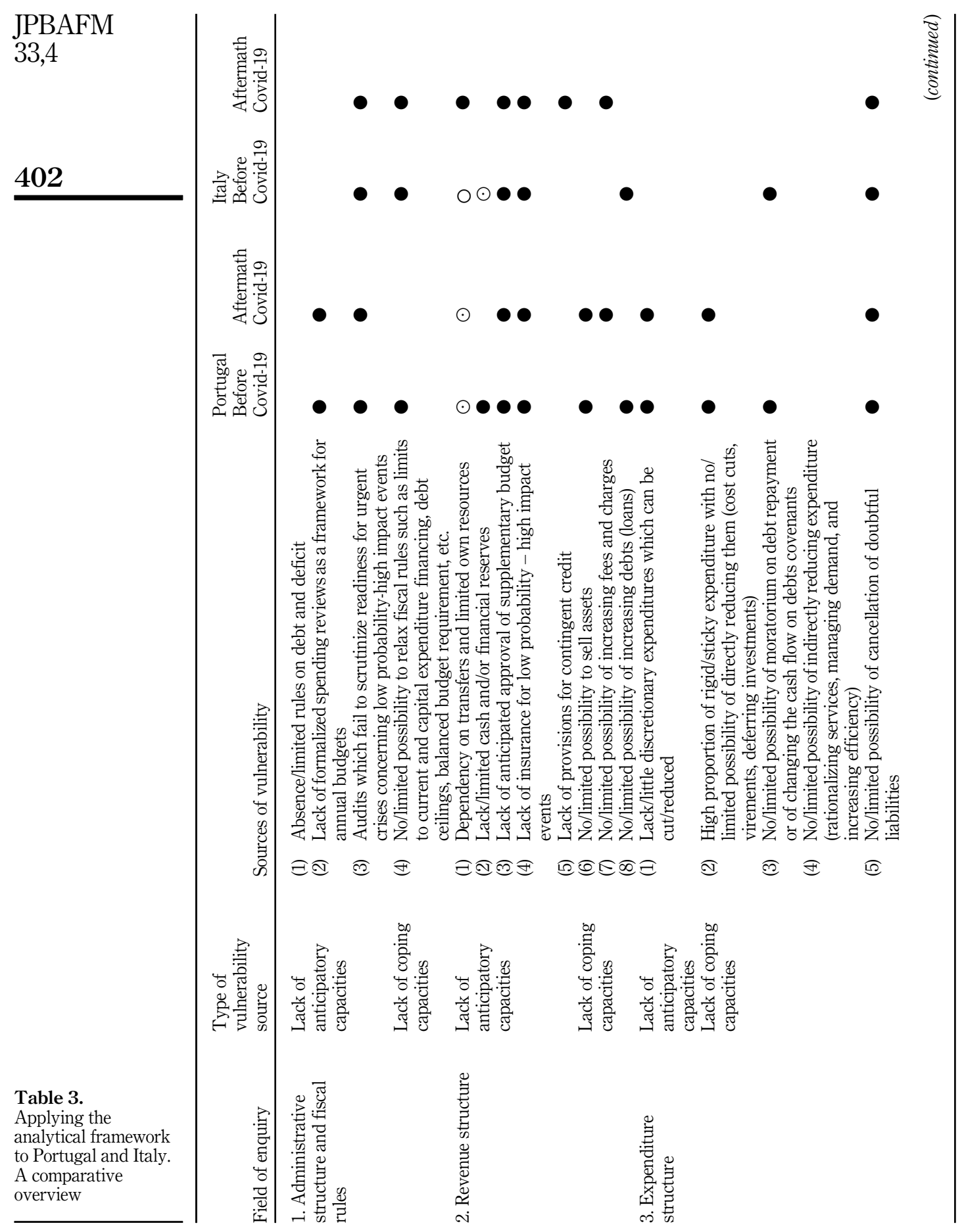



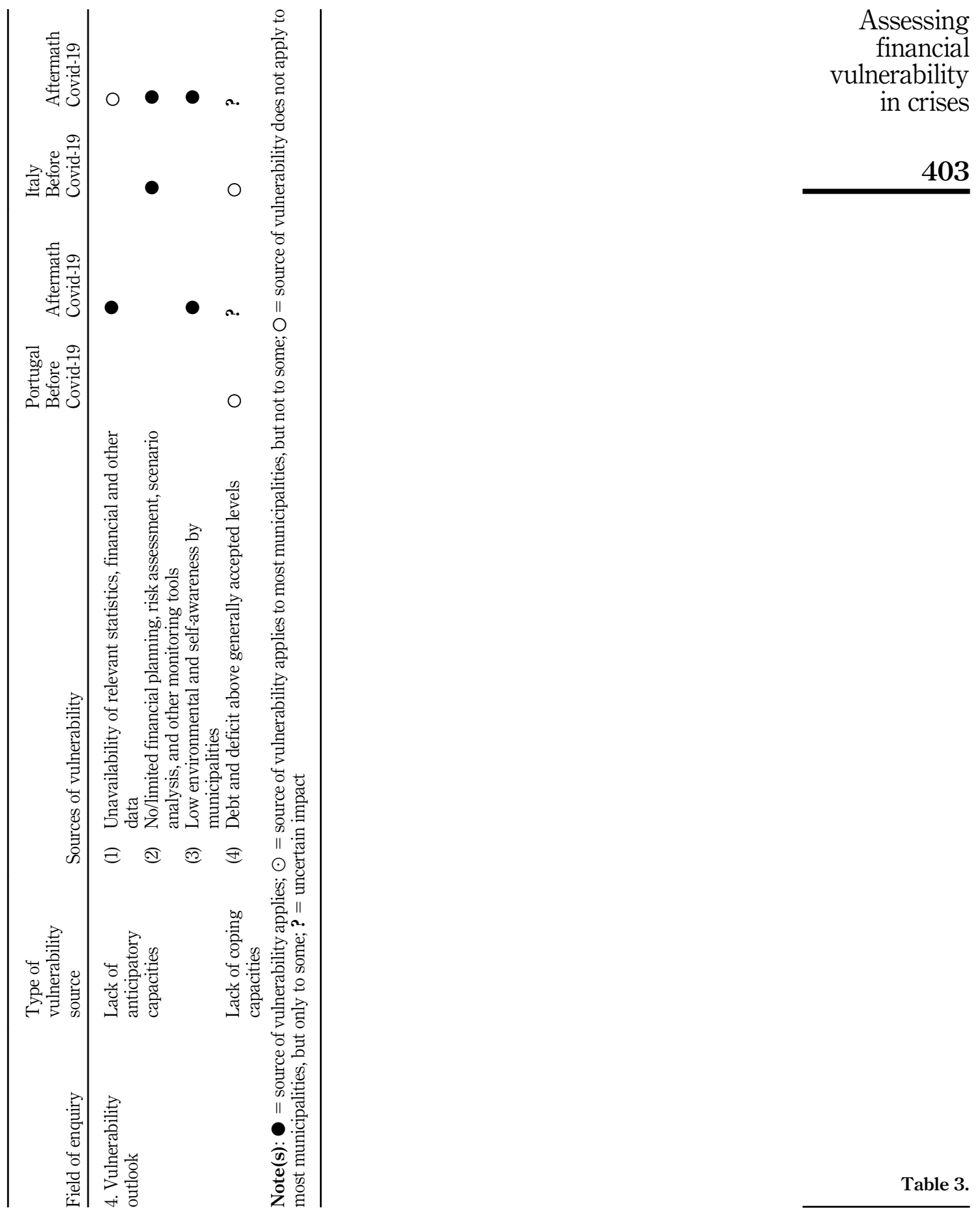

Table 3. 
JPBAFM 33,4 decentralization reform were suspended, while in Italy deferrals were limited to annual budget approval. In Portugal the central government temporarily lifted stringent fiscal measures, because of the known financial vulnerability of most municipalities. The main measures concerned temporarily relaxing debt limitations, anticipating transfers and cash budgetary surpluses, a moratorium on the amortization of financial assistance loan contracts, and allowing for extra non-estimated pandemic-related expenditure. Also, administrative procedures were relaxed, namely concerning public procurement bids. In Italy there was no lifting of fiscal measures to enhance municipalities' coping capacities and insufficient contingent credit. Provisions specific to municipalities can be summed up into four types: postponing revenue collection deadlines during the lockdown period, cash advances as an immediate alleviation measure, relief grants in lieu of local taxes and fee-related revenue reduction, and deferring of one year the payment of mortgage capital instalment. In both countries, audits fail to scrutinize the readiness of municipalities for global shocks.

Hence, new resources to face the pandemic were provided mainly by cash advances and short-term loans, while no supplementary budgets or insurance contracts for low-probability high-impacts were available. A closer look at Tables 2 and 3 reveals that in both countries the revenue structure affects municipalities financial vulnerability differently, depending on: their size, their degree of financial dependency on central government transfers, and their capacity to collect their own revenues. In both countries, large and more financially independent municipalities are ironically likely to be more affected by the crisis, given the disproportionate impact on their own revenue and the impossibility to increase fees and charges during the crisis. On the contrary, municipalities considered to be more financially vulnerable before Covid-19, that is those more financially dependent from central and regional governments, and with a problematic current balance, are likely to be less affected by the Covid-19 crisis. This is because their main revenue source, grants, is unlikely to be cut. In the long run, in both countries, municipalities may end up suffering from further limitations to their financial autonomy (Jorge, 2015).

As far as local expenditures are concerned, they are probably more rigid in Portugal, but both countries enjoy some discretionary expenditures which can be diverted to more needing areas. The net effect of the pandemic on expenditures is still unknown, yet in both Portugal and Italy initiatives were introduced at least to reduce debt servicing. In neither of the countries it is possible to cancel doubtful liabilities, whether before or in the aftermath of the crisis. The main challenge municipalities are facing concerns finding a balance between maintaining financial sustainability with Covid-19 induced higher spending and reduced revenue.

Overall, systemic measures were taken relying at best on historical data, without measuring and profiling vulnerability as the crisis developed, despite financial control by the central government continues to be in place in both countries. Only in a second instance Italy could rely on survey data from large municipalities and Portugal decided to start collecting similarly unofficial information, but both countries appear to lack a timely monitoring system. This has been emphasized by the different nature of Covid-19 with respect to other crises: the effects of the pandemic on local finances were large-scale and immediate. As a result, with the crisis, municipalities in both countries have lost their environmental and selfawareness.

Lastly, considering that most resources were provided as debt, that relief funds are deemed too low, and that capital debt instalments have just been postponed, it can be asserted that local financial imbalances have simply been deferred.

\section{Final remarks}

This study has developed an analytical framework to appreciate the impact of transboundary crisis on municipal financial vulnerability. The model has placed a crucial role in analyzing 
the consequences of the Covid-19 pandemic on Portuguese and Italian municipalities. The main benefit from applying the analytical framework is that it has allowed to map and systematize the issues that influenced municipal financial vulnerability considering both spatial contingencies and time dynamics.

The proposed analytical model has revealed both solid and flexible enough to accommodate the experience of at least two jurisdictions using various indicators and has allowed some interesting considerations to emerge. For example, it led to find out that across countries municipalities which were traditionally considered less vulnerable, as they enjoy a higher proportion of own revenues, have revealed more financially vulnerable than municipalities which depend on transfers that were augmented, rather than cut as during the 2008 crisis. Consequently, the proposed framework helps better appreciate the sources of vulnerability and its contingent nature, in space and time: while in 2008 more financially autonomous municipalities suffered less; with Covid-19 they appear, so far, worse off. Time will tell whether in the medium and long run their resilience will prevail and whether policies implemented in the aftermath of the crisis will have the expected effects.

Therefore, such an evaluation tool may be useful for both academic and public policy purposes to further appreciate municipal financial vulnerability, especially during crises with such global depth and breath as the Covid-19 pandemic. The framework also could allow municipalities to better manage their financial vulnerability, strengthening their anticipatory and copying capacities within their institutional framework of established administrative structure and fiscal rules. Furthermore, oversight authorities may use the framework to better support the mechanisms that can help municipalities become less financially vulnerable or, at least, more aware of their financial vulnerability.

Lastly, applying the model has also highlighted issues that need to be explored further. Future research could develop in different areas: (a) investigating financial vulnerability at individual municipal level or at cluster level to deepen the investigation when conditions and impacts are not homogeneous within a country; (b) developing further the analytical framework, for example considering related indicators developed in the literature, in order to arrive at indexing financial vulnerability to enhance comparability and (c) evaluating sources and indicators of financial vulnerability across other countries and other transboundary crises, to verify, specify and enrich them further. The analytical framework has been developed on sound premises as it was deduced from the literature and illustrated by applying it to two countries, but it would benefit from being reconsidered, stretched and applied further.

\section{References}

Ahrens, T. and Ferry, L. (2020), "Financial resilience of English local government in the aftermath of COVID-19", Journal of Public Budgeting, Accounting and Financial Management, Vol. 32 No. 5, pp. 813-823, doi: 10.1108/JPBAFM-07-2020-0098.

ANCI - Associazione Nazionale Comuni Italiani (2020), "Audizione informale ANCI presso le commissioni bilancio riunite Camera e Senato per la conversione del "DL Rilancio"', available at: https://finanze.regione.emilia-romagna.it/documenti-di-finanza/audizione-anci-dl-34-rilancio28-05-2020.pdf (accessed 14 July 2020).

Anessi-Pessina, E., Barbera, C., Langella, C., Manes-Rossi, F., Sancino, A., Sicilia, M. and Steccolini, I. (2020), "Reconsidering public budgeting after the COVID-19 outbreak: key lessons and future challenges", Journal of Public Budgeting, Accounting and Financial Management, Vol. 32 No. 5, pp. 957-965.

ANMP - Associação Nacional dos Municípios Portugueses (2020), Os municípios no contexto da pandemia Covid-19, Legislação publicada com relevo para as autarquias locais, Circular Nos 33/2020, 18 de maio.

\section{Assessing financial vulnerability in crises}


JPBAFM 33,4

Arunachalam, M., Chen, C. and Davey, H. (2017), "A model for measuring financial sustainability of local authorities: model development and application", Asia-Pacific Management Accounting Journal, Vol. 12 No. 1, pp. 39-76.

Barbera, C., Jones, M., Korac, S., Saliterer, I. and Steccolini, I. (2017), "Governmental financial resilience under austerity in Austria, England and Italy: how do local governments cope with financial shocks?”, Public Administration, Vol. 95 No. 3, pp. 670-697.

Barbera, C., Jones, M., Korac, S., Saliterer, I. and Steccolini, I. (2019), "Local government strategies in the face of shocks and crises: the role of anticipatory capacities and financial vulnerability", International Review of Administrative Sciences, Vol. 87 No. 1, pp. 154-170, doi: 10.1177/ 0020852319842661.

Barbera, C., Guarini, E. and Steccolini, I. (2020), "How do governments cope with austerity? The roles of accounting in shaping governmental financial resilience", Accounting, Auditing and Accountability Journal, Vol. 33 No. 3, pp. 529-558.

Bastida, F., Guillamon, M.D. and Benito, B. (2014), "Explaining interest rates in local government borrowing", International Public Management Journal, Vol. 17, pp. 45-73.

Berne, R. and Schramm, R. (1986), The Financial Analysis of Governments, Prentice Hall, Englewood Cliffs, NJ.

Bettoni, G. (2017) "Constitutional reform and territorial organisation in Italy", in Ruano, J.M. and Profirain, M. (Eds), Palgrave Handbook of Decentralization. Palgrave McMillan, Cham, pp. 103-122.

Bespalova, M. and Knud, A. (2013), "Local and regional democracy in Italy", Council of Europe, CG(24)8, available at: https://rm.coe.int/168071a5e9 (accessed 14 July 2020).

Bisogno, M., Cuadrado-Ballesteros, B., Santis, S. and Citro, F. (2019), "Budgetary solvency of Italian local governments: an assessment", International Journal of Public Sector Management, Vol. 32 No. 2, pp. 122-141.

Boin, A. and Lodge, M. (2016), "Designing resilient institutions for transboundary crisis management: a time for public administration”, Public Administration, Vol. 94 No. 2, pp. 289-298.

Brusca, I., Manes Rossi, F. and Aversano, N. (2015), "Drivers for the financial condition of local government: a comparative study between Italy and Spain", Lex Localis - Journal of Local SelfGovernment, Vol. 13 No. 2, pp. 161-184.

Cabaleiro, R., Buch, E. and Vaamonde, A. (2013), "Developing a method to assessing the municipal financial health", The American Review of Public Administration, Vol. 43 No. 6, pp. 729-751.

Capalbo, E. and Grossi, G. (2014), "Assessing the influence of socioeconomic drivers on Italian municipal financial destabilization”, Public Money and Management, Vol. 34 No. 2, pp. 107-114.

Capeci, J. (1994), "Local fiscal policies, default risk, and municipal borrowing costs", Journal of Public Economics, Vol. 53 No. 3, pp. 73-89.

Cohen, S., Karatzimas, S. and Naoum, V.-C. (2017), "The sticky cost phenomenon at the local government level: empirical evidence from Greece", Journal of Applied Accounting Research, Vol. 18 No. 4, pp. 445-463.

Davies, S. (2011), "Regional resilience in the 2008-2010 downturn: comparative evidence from European countries", Cambridge Journal of Regions, Economy and Society, Vol. 4 No. 3, pp. 369-382.

de Jong, M. and Ho, A.T. (2020), "Emerging fiscal health and governance concerns resulting from COVID-19 challenges", Journal of Public Budgeting, Accounting and Financial Management, Vol. 33 No. 1, doi: 10.1108/JPBAFM-07-2020-0137.

Downing, R.G. (1991), "Urban county fiscal stress: a survey of public officials' perceptions and government experiences", Urban Affairs Quarterly, Vol. 27, pp. 314-325.

Fernandes, M.J., Camões, P., Jorge, S., Teixeira, A. and Abreu, A.R. (2019), Anuário financeiro dos municípios portugueses - 2018; Edição do CICF/IPCA e CICP/UM, Ordem dos Contabilistas Certificados, Lisboa. 
Geissler, R., Hammerschmid, G. and Raffer, C. (2019), Local Public Finance in Europe, Bertelsmann Stiftung, Berlin.

Grossi, G. and Cepiku, D. (2014), "Financial sustainability and cutback management: global issues for public organizations. Editorial”, Public Money and Management, Vol. 34 No. 2, pp. 79-81.

Grossi, G., Ho, A.T. and Joyce, P.G. (2020), "Budgetary responses to a global pandemic: international experiences and lessons for a sustainable future", Journal of Public Budgeting, Accounting and Financial Management, Vol. 32 No. 5, pp. 737-74.

Groves, M., Godsey, W. and Shulman, M. (1981), "Financial indicators for local governments”, Public Budgeting and Finance, Vol. 1 No. 2, pp. 5-19.

Hochrainer, S. (2006), Macroeconomic Risk Management Against Natural Disasters, Deutscher Universitats-Verlag, Wiesbaden.

Jacob, B. and Hendrick, R. (2012), "Assessing the financial condition of local governments: what is financial condition and how is IT measured?", in Levine, H., Justice, B.J. and Scorsone, E.A. (Eds), Handbook of Local Government Fiscal Health, Jones \& Bartlett Publishers, Burlington, Massachusetts, pp. 11-40.

Jorge, S. (2015), “Autonomia e (In)Dependência financeira dos municípios”, de Sousa, L., Tavares, A.F., da Cruz, N.F. and Jorge, S. (Eds), A Reforma do Poder Local em Debate, ICS - Imprensa de Ciências Sociais, Lisbon, pp. 145-151.

Kuhlmann, S. and Wollmann, H. (2014), Introduction to Comparative Public Administration: Administrative Systems and Reforms in Europe, Edward Elgar, Cheltenham.

Lobo, F.H. and Ramos, P. (2011), “O enquadramento legal do endividamento municipal em Portugal”, Revista Portuguesa de Estudos Regionais, Vol. 28, pp. 57-69.

Lodge, M. and Hood, C. (2012), "Into an age of multiple austerities? Public management and public service bargains across OECD countries”, Governance, Vol. 25, pp. 79-101.

Maher, C.S. and Deller, S.C. (2011), "Measuring municipal fiscal condition: do objective measures of fiscal health relate to subjective measures?", Journal of Public Budgeting, Accounting and Financial Management, Vol. 23 No. 3, pp. 427-450.

Maher, C.S., Hoang, T. and Hindery, A. (2020), "Fiscal responses to COVID-19: evidence from local governments and nonprofits", Public Administration Review, Vol. 80 No. 4, pp. 644-650.

Martell, C.R. (2008), "Fiscal institutions of Brazilian municipal borrowing", Public Administration and Development, Vol. 28, pp. 30-41.

Mikesell, J.L. (2013), Fiscal Administration, 8th ed., Wadsworth, Belmont, CA.

MLSP - Ministry of Labour and Social Policies and ANCI - Associazione Nazionale Comuni Italiani (2020), "I servizi sociali al tempo del coronavirus", available at: https://www.fondiwelfare.it/wpcontent/uploads/2020/07/I-Servizi-Sociali-al-tempo-del-Coronavirus.pdf (accessed 14 July 2020).

Nemec, J. and Špaček, D. (2020), “The Covid-19 pandemic and local government finance: Czechia and Slovakia”, Journal of Public Budgeting, Accounting and Financial Management, Vol. 32 No. 5, pp. 835-846, doi: 10.1108/JPBAFM-07-2020-0109.

OECD (2020a), OECD Economic Outlook, Vols 2020/1, No. 107, OECD Publishing, Paris.

OECD (2020b), The Territorial Impact of COVID-19: Managing the Crisis Across Levels of Government, OECD Publishing, Paris.

OECD and World Bank (2019), Fiscal Resilience to Natural Disasters: Lessons from Country Experiences, OECD Publishing, Paris.

Ongaro, E. (2008), "Introduction: the reform of public management in France, Greece, Italy, Portugal and Spain", International Journal of Public Sector Management, Vol. 21 No. 2, pp. 101-117.

Padovani, E. (2020), "Finanza locale: impatto del covid-19. Gli impatti della pandemia sulle finanze delle amministrazioni comunali", working paper, University of Bologna, Bologna, 30 June 2020 .

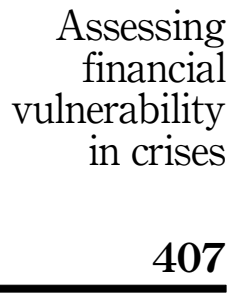


JPBAFM 33,4

Persson, T. and Tabellini, G. (1996), "Federal fiscal constitutions: risk sharing and moral hazard", Econometrica, Vol. 64 No. 3, pp. 623-646.

Peters, B.G. (2011), "Governance responses to the fiscal crisis: comparative perspectives", Public Money and Management, Vol. 31 No. 1, pp. 75-80.

Pollitt, C. (2008), Time, Policy, Management: Governing with the Past, Oxford University Press, Oxford.

Pollitt, C. and Bouckaert, G. (2017), Public Management Reform: A Comparative Analysis into the Age of Austerity, Oxford University Press, Oxford.

Pollner, J.D., Camara, M. and Martin, L. (2001), Honduras. Catastrophe Risk Exposure of Public Assets. An Analysis of Financing Instruments for Smoothing Fiscal Volatility, World Bank, Washington, DC.

Raffer, C. and Padovani, E. (2019), "Italy", in Geissler, R., Hammerschmid, G. and Raffer, C. (Eds), Local Public Finance in Europe, Bertelsmann Stiftung, Berlin, pp. 141-153.

Saliterer, I., Jones, M. and Steccolini, I. (2017), "Introduction”, in Steccolini, I., Jones, M. and Saliterer, I. (Eds), Governmental Financial Resilience, Public Policy and Governance, Emerald Publishing, Bingley, pp. 1-16.

Seawright, J. and Gerring, J. (2008), "Case study selection techniques in case study research: a menu of qualitative and quantitative options", Political Research Quarterly, Vol. 61 No. 2, pp. 294-308.

Steccolini, I., Jones, M. and Saliterer, I. (2017), “Conclusion”, in Steccolini, I., Jones, M. and Saliterer, I. (Eds), Governmental Financial Resilience, Public Policy and Governance, Emerald Publishing, Bingley, pp. 229-240.

Trombetta, M. (2020), "Editorial”, Journal of Accounting and Public Policy, Vol. 39 No. 2, pp. 1-2.

UCLG (2019), "GOLD V 2019. The localization of the global agendas. How local action is transforming territories and communities. Fifth global report on decentralization and local democracy", $U C L G$, Barcelona, available at: https://www.gold.uclg.org/reports/gold-v?qt-reports=0\#qtreports (accessed 22 September 2020).

Wällstedt, N., Grossi, G. and Almqvist, R. (2014), "Organizational solutions for financial sustainability: a comparative case study from the Swedish municipalities", Journal of Public Budgeting, Accounting and Financial Management, Vol. 26 No. 1, pp. 181-218.

Walker, B., Carpenter, S., Anderes, J., Abel, N., Cumming, G., Jansen, M., Lebel, L., Norberg, J., Perereson, G. and Pichard, R. (2002), "Resilience management in social-ecological systems: a working hypothesis for a participatory approach", Conservation Ecology, Vol. 6 No. 1, available at: http://www.consecol.org/vol6/iss1/art14/ (accessed 19 September 2020).

Zafra-Gómez, J.L., López-Hernández, A.M. and Hernández-Bastida, A. (2009), "Developing an alert system for local governments in financial crisis", Public Money and Management, Vol. 29 No. 3, pp. 175-181.

\section{Corresponding author}

Emanuele Padovani can be contacted at: emanuele.padovani@unibo.it

For instructions on how to order reprints of this article, please visit our website:

www.emeraldgrouppublishing.com/licensing/reprints.htm

Or contact us for further details: permissions@emeraldinsight.com 